\title{
Antimicrobial Activity and Phytochemical Analysis of Jatropha Curcas Plant against Some Selected Microorganisms
}

\author{
M. O. Arekemase (Corresponding author) \\ Department of Microbiology, University of Ilorin, Ilorin, Kwara State, Nigeria \\ Tel: 234-803-042-0658Ｅ-mail: arekemase.om@unilorin.edu.ng
}

R. M. O. Kayode

Department of Home economics and Food Science, University of Ilorin, Ilorin, Nigeria

Tel: 234-803-585-0545 E-mail: kayodermosnr@yahoo.com

\author{
A.E Ajiboye \\ Dept of Microbiology, Kwara State University, Malete Via Ilorin, Nigeria \\ Tel: 234-806-110-2397 E-mail: adeyinka.ajiboye@kwasu.edu.ng
}

Received: February 25, 2011 Accepted: March 8, 2011 doi:10.5539/ijb.v3n3p52

\begin{abstract}
Jatropha curcas is an ornamental plant which is also employed to cure various infections in traditional medicine. The hexane, ethanolic and aqueous extracts and latex of this plant were analysed phytochemically and screened against different microorganisms responsible for various human infections. Phytochemical analysis of the extracts and latex revealed the presence of many secondary metabolites including steroids, alkaloids and saponins. Ethanolic extract was found to be richer than hexane extract and aqueous extract as well as latex. The extracts and latex displayed potent antimicrobial activity against Staphylococcus aureus, Neisseria gonorrhoea, Pseudomonas aeruginosa, Escherichia coli, Candida albicans, and Aspergillus flavus, giving minimum inhibitory concentration as low as $0.5 \mathrm{~mL}$. The results confirmed the potency of this plant in treating human infections including sexually transmitted diseases.
\end{abstract}

Keywords: Jetropha curcas, Microorganisms, Extract, Latex, Phytochemical, Inoculum

\section{Introduction}

Anti-microbial agents are substances that kill microorganisms or inhibit their growth. They are widely employed to cure bacterial diseases. Antimicrobial agents that reversibly inhibit growth of bacteria are called bacteriostatic whereas those with irreversible lethal action on bacteria are known as bactericidal (Rajesh and Rattan, 2008).

Ideally, antimicrobial agents disrupt microbial processes or structures that differ from those of the host. They may damage pathogens by hampering cell wall synthesis, inhibiting microbial protein and nucleic acid synthesis, disrupting microbial membrane structure and function, or blocking metabolic pathways through inhibition of key enzymes (Willey et at., 2008).

Haslam et al. (1989) reported that plant extracts and their products are used in many parts of the world as the active principles in herb remedies. They are used locally in the treatment of infections, many centuries before scientific studies were discovered.

Before an antimicrobial agent is accepted for use in human beings it must demonstrate most, if not all, of the following properties: selective toxicity (it should act on bacteria without damaging the host tissues); it should be bactericidal rather than bacteriostatic; it should be effective against a broad range of bacteria; it should not be allergic; it should remain active in plasma, body fluids etc.; it should be stable and preferably water soluble; desired levels should be reached rapidly and maintained for adequate period of time; it should not give rise to resistance in bacteria; it should have long shelf life; it should not be expensive (Rajesh and Rattan, 2008). 
The effectiveness of chemotherapeutic agents depend on many factors, some of which include; the route of administration and location of the infection, the presence of interfering substances, the concentration of the drug in the body, the nature of the pathogen, the presence of drug allergies, and another factor that should not be overlooked is the resistance of microorganisms to the drug. The increasing number and the variety of drug resistance pathogen is a serious public health problem. Bacteria often become resistant in several different ways. Unfortunately, a particular type of resistance mechanism is not confined to a single class of drugs. Two bacteria may use different resistance mechanisms to withstand the same chemotherapeutic agent. Furthermore, resistant mutants arise spontaneously and are then selected for in the presence of the drug. Bacteria can become resistant to a drug by excluding it from cell, pumping the drug out of the cell, enzymatically altering it, modifying the target enzymes or organelles to make it less drug sensitive (Willey et al., 2008).

There are thousands of species of medicinal plants used globally for the cure of different infections. These plants are used as antimicrobial agents and several works have been carried out by scientists to find out its scientific basis (Omotayo, 1998). Some of these plants include; Anacardium occidentale (cashew), Pilostigma recticulatum, Anogeissus leiocarpa, Enantia chlorantha, Senna occidentalis, Jatropha curcas ("Lapalapa"), Azadirachta indica ("Dongoyaro") etc. A great number of antibacterial agents exist for various purposes; some of these are usually in the form of plants. The action of these plants on microorganisms have been found to be due to the presence of certain substances such as alkaloids, glycosides, volatile oils, gums, tannins, steroids, saponins, phlobatannins, flavonoids and a host of other chemical compounds referred to as secondary metabolites that are present in them (Kochlar, 1986; Sofowora, 1993; Oyagade et al., 1999).

Medicinal plants like $J$. curcas have played a major role in the treatment of various diseases including bacterial and fungal infections. The extracts of many Jatropha species including J. curcas displayed potent cytotoxic, anti-tumor and anti-microbial activities in different assays. The latex of $J$. curcas also showed antibacterial activity against Staphylococcus aureus (Thomas, 1989), however the antimicrobial activity of the other parts have not been fully investigated. The objectives of this study were (1) to investigate the effectiveness of Jetropha curcas against some selected microorganisms which are known to cause diseases in human beings (2) to determine the phytochemicals present inJetropha curcas (3) to find out which of the methods of extraction contained the highest concentration of the active principle of Jetropha curcas

\section{Materials and Methods}

\subsection{Collection of Plant Materials}

Roots of Jatropha curcas plant were collected in clean polythene bags and the latex was collected into specimen bottles at Shao garage area Ilorin, Kwara State, Nigeria. The leaves, the stems, the fruits and the roots were taken to Department of Plant Biology, Faculty of Science, University of Ilorin, Ilorin, Kwara State for proper identification and authentication. The roots were washed with distilled water sliced/cut into pieces and air-dried. The latex was kept in the refrigerator at $4^{\circ} \mathrm{C}$.

\subsection{Preparation of Extracts}

Aqueous, ethanolic, and hexane extracts of the roots of the plant was prepared. The plant roots were grounded with mortar and pestle.

Aqueous extract: Five grams of the grounded roots was measured into a conical flask and $20 \mathrm{~mL}$ of sterile distilled water was added, covered with a cork, mixed together properly and left on the shaker at 100 revolution per minute for 24 hours after which the extract was filtered and squeezed through four layers of muslin cloth. The filtrate was then centrifuged at 2,000 revolution per minute (r.p.m.) for 5 minutes after which it was decanted. The pellet was discarded and the supernatant was sterilized by using the membrane filtration unit with type $\mathrm{HC}$ filters. The filtrate obtained was stored in sterile McCartney bottles and kept in the refrigerator at $4^{\circ} \mathrm{C}$ and later used for antimicrobial tests.

Ethanolic extract: Five grams of the grounded roots was measured into a conical flask and $20 \mathrm{~mL}$ of $95 \%$ ethanol was added, covered with a cork, mixed together and left on the shaker at 100 r.p.m. for 24 hours after which the extract was filtered and squeezed through four layers of muslin cloth. The filtrate was then centrifuged at 2,000 r.m.p. for 5 minutes after which it was decanted. The pellet was discarded and the supernatant was sterilized by using the membrane filtration unit with type HC filters. The filtrate obtained was stored in sterile McCartney bottles and kept in the refrigerator at $4^{\circ} \mathrm{C}$ and later used for antimicrobial tests.

Hexane extract: Five grams of the grounded roots was measured into a conical flask and $20 \mathrm{~mL}$ of hexane was added, covered with a cork, mixed together and left on the shaker at 100 r.p.m. for 24 hours after which the extract was filtered and squeezed through four layers of muslin cloth. The filtrate was then centrifuged at 2,000 revolution 
per minutes for 5 minutes after which it was decanted. The pellet was discarded and the supernatant was sterilized by using the membrane filtration unit with type $\mathrm{HC}$ filters. The filtrate obtained was stored in sterile McCartney bottles and kept in the refrigerator at $4^{\circ} \mathrm{C}$ and later used for antimicrobial tests.

Latex from the plant was collected into sterile specimen bottles and centrifuged at 2,000 r.p.m. for 5 minutes after which it was sterilized using the membrane filtration unit. The sterile filtrate obtained was stored in sterile McCartney bottles and kept in the refrigerator at $4^{\circ} \mathrm{C}$ and later used for antimicrobial tests.

\subsection{Sterility Test of the Plant Extracts and Latex}

Each of the above extracts (hexane extract, ethanolic extract and aqueous extract) and latex were tested for growth or contaminants. This was carried out by inoculating $1 \mathrm{ml}$ of each of them on nutrient agar and incubated at $37^{\circ} \mathrm{C}$ for 24 hours. The plates were observed for growth. No growth in the extracts and latex after incubation indicated that the extracts and latex were sterile. The extracts and latex were then assessed for antimicrobial activity.

\subsection{Collection and Maintenance of Test Organisms}

The test organisms were selected based on their availability; although the choice attempted selection of medically important pathogenic bacterial and fungi. Care was taken to cover morphologically broad range of microorganisms. Hence four bacteria isolates and two fungi (yeast and mould) were used for the test. The organisms were collected from University of Ilorin Teaching Hospital Ilorin, Kwara State, Nigeria. The organisms were Staphylococcus aureus, Neisseria gonorrhoea, Pseudomonas aeruginosa, Escherichia coli, Candida albicans, and Aspergillus flavus. The bacteria were maintained on nutrient agar slant and stored in the refrigerator at a temperature of $4^{\circ} \mathrm{C}$. Candida albicans was maintained on Sabouraud's Dextrose Agar (SDA) and stored in the refrigerator at a temperature of $4^{\circ} \mathrm{C}$. Both bacteria and Candida albicans were subcultured onto fresh media at regular intervals while Aspergillus flavus was cultured on Potato Dextrose Agar (PDA) and subcultured at regular intervals until it was used for the test.

\subsection{Phytochemical Screening of the Extracts of the Root and the Latex of Jatropha Curcas}

The methods described by Odebiyi and Sofowora (1978) were used to test for the presence of saponins, tannins, phenolics and alkaloids, Lieberman Burchad reaction as described by Herburne (1973) was used to test for steroids, while the Salkowski test was used to test for the presence of glycosides.

Testing for saponins: Each extract $(0.5 \mathrm{~g})$ was mixed with water in test tube. Foaming which persisted on warming was taken as an evidence for the presence of saponins.

Testing for tannins and phenolics: Each extract $(0.5 \mathrm{~g})$ was separately stirred with $10 \mathrm{~mL}$ of distilled water and then filtered. Few drops of $5 \% \mathrm{FeCl}_{3}$ reagent was added to the filtrate. Blue-black or blue-green colouration or precipitation was taken as an indication of the presence of phenolics and tannins.

Testing for alkaloids: Each extract $(0.5 \mathrm{~g})$ was stirred with $5 \mathrm{~mL}$ of $1 \% \mathrm{HCl}$ on a steam bath. The solution obtained was filtered and one $1 \mathrm{~mL}$ of the filtrate was treated with a few drops of Mayer's reagent. The turbidity of the extract filtrate on addition of Mayer's reagent was taken as evidence of the presence of alkaloids in the extracts.

Testing for steroids: $0.5 \mathrm{~g}$ of each extract was separately added with 5 drops of acetic anhydride and then a drop of concentrated $\mathrm{H}_{2} \mathrm{SO}_{4}$. The mixture was steamed for 1 hour and neutralized with sodium hydroxide $(\mathrm{NaOH})$, followed by the addition of chloroform. The appearance of a blue-green colour indicated the presence of steroid.

Testing for glycosides: $0.5 \mathrm{~g}$ of each extract was dissolved in $2 \mathrm{~mL}$ of chloroform. Tetraoxosulphate VI acid $\left(\mathrm{H}_{2} \mathrm{SO}_{4}\right)$ was carefully added to form a lower layer. A reddish brown colour at the interface indicated the presence of a steroidal ring, that is, a glycone portion of the cardiac glycosides

\subsection{Antibacterial Test}

The antibacterial properties of the root extracts and the latex were determined using the agar diffusion method of Bookye-Yiadam (1979). Twenty-four hour old broth culture of test organisms (standardized inocula) were swabbed onto sterile Mueller Hinton Agar in Petri dishes using sterile cotton swabs. A sterile stainless steel cork borers of size $12 \mathrm{~mm}$ in diameter was used to make wells on the plates. The holes were filled with $0.1 \mathrm{~mL}, 0.5 \mathrm{~mL}$ and $1.0 \mathrm{~mL}$ of the root extracts, while $0.1 \mathrm{~mL}, 0.5 \mathrm{~mL}$ and $1.0 \mathrm{~mL}$ of the latex was used. Each well was labeled appropriately. Control experiments were also carried out where the holes were filled with sterile distilled water. The sterile distilled water and the extracts were incorporated into the holes by the use sterile $2 \mathrm{~mL}$ syringes. The inoculated Petri dishes were left for an hour at room temperature for the extracts to diffuse before the growth of organisms commenced. The plates were incubated at $37^{\circ} \mathrm{C}$ for 24 hours after which the results were read by measuring the diameters of zones of inhibition around the wells with the aid of a metric ruler and recorded. The antimicrobial studies were done in triplicates and diameters of zones of inhibition ( $\mathrm{mm}$ ) are expressed as Means 
and Standard errors on Means. A larger zone of inhibition indicated the test substance was active against the bacteria, a small zone may mean that the substance was only slightly active against the organism, and no zone may mean no activity, but this might also mean that the substance was unable to diffuse through the agar.

\subsection{Antifungal Test}

The pour plate method was used for the assay of the effect of the root extracts and the latex against Aspergillus flavus. Sterile root extracts were introduced into McCartney bottles containing respectively of sterile Potato Dextrose Agar. For the latex $0.1 \mathrm{~mL}, 0.5 \mathrm{~mL}$, and $1.0 \mathrm{~mL}$ were incorporated into $19.9 \mathrm{~mL}, 19.5 \mathrm{~mL}$, and $19 \mathrm{~mL}$ of the medium respectively. These were dispensed of Petri dishes and allowed to set. Each plate was bored with sterile cork borer of $12 \mathrm{~mm}$ in diameter. The plates were inoculated by using a sterile cork borer $12 \mathrm{~mm}$ in diameter to cut the advancing edges of young cultures of $A$. flavus which were used to replace the ones cut on the plate using sterile forceps. Control experiments were also setup performed without extract and latex on $20 \mathrm{~mL}$ medium. Plates were incubated in upright position at $30^{\circ} \mathrm{C}$ for 72 hours after which the results were read.

Agar diffusion method previously described for antibacterial test was used in determining antifungal action of the root extract and latex against Candida albicans, $0.1 \mathrm{~mL}, 0.5 \mathrm{~mL}$ and $1.0 \mathrm{~mL}$ of the extracts were incorporated into the wells in the Sabouraud's Dextrose Agar plates containing the organism. The wells were made by using sterile cork borers $12 \mathrm{~mm}$ in diameter. For the latex, $0.1 \mathrm{~mL}, 0.5 \mathrm{~mL}$ and $1.0 \mathrm{~mL}$ were used. Control experiments were also carried out where the holes on the agar plates were filled with sterile distilled water. Plates were left at room temperature for one hour before incubation at $30^{\circ} \mathrm{C}$ for 48 hours. Diameter of zone of inhibition due to the activity of the extracts and latex were measured after the period of incubation.

\subsection{Determination of Minimum Inhibitory Concentration (MIC) of the Latex and Root Extracts}

The minimum inhibition concentration was determined against bacteria after the antibacterial test had been performed. Nutrient Agar was used and agar diffusion method was employed for those organisms whose growth could be inhibited at lower concentrations of the extracts, while pour plate method was used for those bacteria whose growths could be inhibited at higher concentrations, that is, those that showed no inhibition at $0.1 \mathrm{~mL}$ to $1.0 \mathrm{~mL}$ of the extracts.

Agar diffusion method was used for those bacteria whose growths were inhibited at $0.5 \mathrm{~mL}$ of the extracts but not $0.1 \mathrm{~mL}, 0.3 \mathrm{~mL}$, while $0.05 \mathrm{~mL}$ of the extracts were tested against those bacteria that were sensitive to $0.1 \mathrm{~mL}$ extracts. Sterile cork borers of diameter $12 \mathrm{~mm}$ was used to bore holes on the plates after seeding the plates with the bacterial strain concerned, left for 1 hour at room temperature and incubated at $37^{\circ} \mathrm{C}$ for 24 hours. Results were read after 24 hours of incubation.

Pour plate method. Nutrient agar of $19.95 \mathrm{~mL}, 19.90 \mathrm{~mL}, 19.70 \mathrm{~mL}, 19.50 \mathrm{~mL} 19.00 \mathrm{~mL}$ and $18.00 \mathrm{~mL}$ were introduced into the McCartney bottles using pipette, sterilized by autoclaving, cooled to about $46^{\circ} \mathrm{C}$ before $0.05 \mathrm{~mL}$, $0.1 \mathrm{~mL}, 0.3 \mathrm{~mL}, 0.5 \mathrm{~mL}, 1.0 \mathrm{~mL}$, and $2.0 \mathrm{~mL}$ of sterile extracts were transferred into the bottles respectively. These were mixed and dispensed into sterile Petri dishes and allowed to set, and then inoculated with bacteria. Control experiments were also carried out by dispensing $20 \mathrm{~mL}$ of nutrient agar without extracts and latex into Petri dish. Plates were incubated at $37^{\circ} \mathrm{C}$ for 24 hours and the results were read after incubation. The above procedure was used for Candida albicans but Sabouraud's Dextrose Agar was used instead of nutrient agar.

Minimum inhibition concentration determination for Aspergillus flavus also followed the antifungal test. Pour plate method was used with $19.95 \mathrm{~mL}, 19.90 \mathrm{~mL}, 19.70 \mathrm{~mL}, 19.50 \mathrm{~mL} 19.00 \mathrm{~mL}$ and $18.00 \mathrm{~mL}$ of the extracts and latex incorporated into $19.95 \mathrm{~mL}, 19.90 \mathrm{~mL}, 19.70 \mathrm{~mL}, 19.50 \mathrm{~mL} 19.00 \mathrm{~mL}$ and $18.00 \mathrm{~mL}$ of Potato Dextrose Agar respectively in McCartney bottles. These were mixed and dispensed into Petri dishes, allowed to set and inoculated with Aspergillus flavus by using a sterile cork borer of $12 \mathrm{~mm}$ in diameter to cut the advancing edges of young cultures of $A$. flavus which were used to replace the ones cut on the plate using sterile forceps. Control experiments were also carried out by dispensing $20 \mathrm{~mL}$ of Potato Dextrose Agar without extracts and latex into Petri dish. The plates were incubated at $30^{\circ} \mathrm{C}$ for 72 hours after which the results were read.

\section{Results and Discussion}

All the extracts except hexane extract of the root were rich in steroids, which are common constituents of plants. Latex also did not possess steroid but it possessed saponins, tannins, alkaloids and glycosides. Alkaloids and tannins are also present in all the root extracts (Table 1), which is in agreement with a previous report by (Rahila et $a l .$, 1994) who reported that plants contained components which were active against microorganisms. All the ethanol extracts were richer in these metabolites than the hexane and aqueous extracts which may be due to its ability to extract more components. 
In this experiment, it was observed that majority of the bacteria were not sensitive to the extracts and latex at lower concentrations of $0.05 \mathrm{~mL}$ and $0.10 \mathrm{~mL}$, unlike at higher concentrations of $0.50 \mathrm{~mL}$ and $1.00 \mathrm{~mL}$. Staphylococcus aureus was observed to be the most sensitive bacterium to the extracts (Table 2 with $6 \mathrm{~mm}$ diameter, and Table 4 with $7 \mathrm{~mm}$ diameter) at $0.10 \mathrm{~mL}$ and was the most sensitive to latex at $1.00 \mathrm{~mL}$ with $22 \mathrm{~mm}$ inhibition zone (Table 5). Aqueous extract was also effective against Staphylococcus aureus with $17 \mathrm{~mm}$ at $1.0 \mathrm{~mL}$, this result was in accordance with the experiment carried out by Aiyelaagbe et al., (2007).

Neisseria gonorrhoea was the most sensitive bacterium to hexane extract with $20 \mathrm{~mm}$ zone of inhibition while Escherichia coli and Pseudomonas aeruginosa were not sensitive to hexane extract with no zone of inhibition (Table 2). It is noteworthy that the ethanol extract of the root showed potent broad spectrum activity against all the bacterial tested (Table 3) but was not effective against Candida albicans. Escherichia coli was the most sensitive to ethanolic extract with $17 \mathrm{~mm}$ inhibition zone (Table 2). Aqueous extract inhibited the growth of all bacteria tested except Pseudomonas aeruginosa (Table 4).

Candida albicans was not sensitive to ethanolic extract and aqueous extract but its growth was inhibited by hexane extract. The latex of Jatropha curcas was not effective against Candida albicans. The hexane extract of the root is the most potent against Candida albicans and the most active against Neisseria gonorrhoea and Staphylococcus aureus.

The result presented in Table 6 showed that lower volume $(0.1 \mathrm{~mL})$ of latex stimulated the growth of Aspergillus flavus, while higher volume $(1.00 \mathrm{~mL})$ reduced its mycelial growth. This result suggested that latex from Jatropha curcas possessed antifungal activity, since the growth of the test fungus was inhibited which agreed with the report made by Fagbenro et al., (1998).

In Table 7 only Staphylococcus aureus and Candida albicans were sensitive to $0.05 \mathrm{~mL}$ and $0.10 \mathrm{~mL}$ of hexane extract of Jatropha curcas root but Escherichia coli and Pseudomonas aeruginosa were not, whereas $0.30 \mathrm{~mL}$ of hexane extract was able to inhibit the growth of Neisseria gonorrhoea. Since this extract failed to inhibit the growth of Escherichia coli and Pseudomonas aeruginosa at lower concentrations attempts were made to test against these bacteria the effects of hexane extract at higher concentrations; $1.50 \mathrm{~mL}, 2.00 \mathrm{~mL}, 2.50 \mathrm{~mL}, 3.00 \mathrm{~mL}$, $3.50 \mathrm{~mL}$ and $4.00 \mathrm{~mL}$ using pour plate method. P. aeruginosa was sensitive at $3.50 \mathrm{~mL}$ while $E$. coli was sensitive at $2.50 \mathrm{~mL}$. Both organisms were sensitive at higher concentrations. Hence, minimum inhibitory concentration for $S$. aureus was $0.05 \mathrm{~mL}$, Neisseria gonorrhoea was $0.2 \mathrm{~mL}$, E. coli was $2.50 \mathrm{~mL}$, and P. aeruginosa was $3.50 \mathrm{~mL}$.

The results presented above indicated that root extracts and latex from Jatropha curcas exhibited antimicrobial properties, thus justifying scientifically their traditional used as medicinal plants. They further suggested that the extracts contain constituents which are active against those strains of organisms tested as earlier reported by Sofowora (1982) that plants traditionally claimed useful in treating wounds should show antimicrobial activities. Therefore, the antimicrobial action of the plant used was not surprising.

In this study, antibacterial test of the root extracts of Jatropha curcas and latex showed that the plant exhibited broad spectrum of activities by inhibiting the growth of four bacteria and two fungi used. It was observed that an increase in the volume of the extracts and latex brought more activity, as shown by the diameters of zone of inhibition.

The latex of Jatropha curcas was observed to be more effective than each of the extracts due to its ability to inhibit all the test bacteria. The screening of the extracts and latex of Jatropha curcas suggested that they show activities against $A$. flavus. The extracts together were found to be effective than latex against $A$. flavus. Both extracts and latex reduced the mycelial growth of $A$. flavus.

The observation made on the minimum inhibitory concentration (MIC) of the extract (Table 7) seemed to correlate with the report that bacteria varied widely in the degree of their susceptibility (Emeruwa, 1982; El-Feraly et al., 1983; and Willey et al., 2008). High minimum inhibitory concentration was observed for bacteria whose growths could not be inhibited at lower volume. In Table 8 ethanolic extract had the lowest concentration of $0.5 \mathrm{ml}$ that reduced mycelia growth, while the other extracts had reduction of mycelia growth at $1.0 \mathrm{ml}$ and $2.0 \mathrm{ml}$ respectively.

It is worth noting that this plant showed activity against microorganisms causing diseases not traditionally used for and since these test organisms are also implicated in a wide variety of infections, it therefore means that constituents of the root extracts and latex of this plant could be very useful in chemotherapy.

\section{Conclusions}

This study has revealed the presence of many secondary metabolites in the roots and latex of Jatropha curcas. It has further confirmed that the plant extracts could be used for the treatment of various infections. The results lend 
acceptance to the folkloric use of this plant in treating microbial infections and shows that $J$. curcas could be exploited for new potent antibiotics

\section{References}

Aiyelaagbe, O.O., Adeniyi, B.A., Fatunsin, O.F. and Arimah, B.D. (2007). In vitro antimicrobial activity and phytochemical analysis of Jatropha curcas roots. International Journal of Pharmacology. 3(1):421-426

Bookye-Yiadam, K. (1979). Antimicrobial Properties of Some West African Medicinal Plants II. Antimicrobial Activity of Aqueous Extract of Cryptolepsis sangumolenta. Quart Journal of Crude Drug Reseach. 17(2):78-80

El-Feraly, F. S.; Cheatham, S. F. and Breedlove, R. L. (1983). Antimicrobial Neoligants of Sassafras randaiense Root. Lloydia. 46(4):493-497.

Emeruwa, A. C. (1982). Antimicrobial Substance from Carica papaya Fruit Extracts. Lloydi: 45(5):123-127

Fagbenro-Beyioku, A.F., Oyibo, W.A. and Anuforom, B.C. (1998). Disinfectant/Antiparasitic Activities of Jatropha curcas. East African Medical Journal. 75:508-511.

Haslam, E., Lilley, T. H., Martin, Y and Magnolotto, R. (1989). Traditional Herbal Medicine; The Roles of Polyphenols, Plants Medica: 4(2):1-8.

Herbune, J. R. (1973). Phytochemical Methods. In: A Guide to Modern Techniques of Plant Analysis. Chapman and Hall London. $161 \mathrm{pp}$.

Kochlar, S. L. (1986). Tropical Crops. In: A Textbook of Economic Botany. Macmillan Publishers Ltd, London and Basingstoke. pp 21-25, 33-34

Omotayo, A. E. (1998). Antibacterial Activity of Some Antimalarial Plants. Proceeding of Nigerian Society for Microbiology. 39:69-72

Oyagade, J. O., Awotoye, O. O., Adewumi, J. T. and Thorpe, H. T. (1999). Antimicrobial Activities of Some Nigerian Medicinal Plants. Screening for Antimicrobial Activity. Bioscience Research Communication.11(3):193-197.

Rajesh, B. and Rattan, L. I. (2008). Essentials of Medical Microbiology. $4^{\text {th }}$ Edition. Jaypee Brothers Medical Publishers (P) Ltd. New Delhi 110002, India. 500 pp

Sofowora, E. A. (1982). Medicinal Plants and Traditional Medicine in Africa. John Wiley and sons, U.S.A. pp $10-40$

Sofowora, E. A. (1993). Medicinal Plants and Traditional Medicine in Africa. Spectrum Books Ltd, Ibadan, Nigeria. $289 \mathrm{pp}$

Thomas, O.O. (1989). Re-examination of the antimicrobial activities of Xylopia aethiopica, Carica papaya, Ocimium gratissimum and Jatropha curcas. Fitoterapia. 60:147-161.

Willey, J. M., Sherwood, L. M. and Woolverton, C. J. (2008). Prescott, Harley and Klein's Microbiology. $7^{\text {th }}$ Edition. McGraw Hill, New York, NY 10020. 1088 pp

Table 1. Phytochemical screening of Jatropha curcas root extracts and latex

\begin{tabular}{|l|c|c|c|c|c|}
\hline \multirow{2}{*}{ Extract } & \multicolumn{5}{|c|}{ PHYTOCHEMICALS } \\
\cline { 2 - 6 } & Saponin & Tannin & Alkaloid & Steroid & glycoside \\
\hline Hexane Extract & + & + & + & - & + \\
\hline Ethanol Extract & ++ & ++ & ++ & ++ & + \\
\hline Aqueous Extract & + & + & + & ++ & + \\
\hline Latex & + & + & + & - & + \\
\hline
\end{tabular}

Key:

,$+=$ Slightly Positive

,$++=$ Positive

,- = Negative 
Table 2. Antimicrobial activity of the hexane extract of Jatropha curcas root on different test organisms

\begin{tabular}{|l|c|c|c|c|}
\hline \multirow{2}{*}{\multicolumn{1}{|c|}{ Organism }} & \multicolumn{4}{|c|}{ Volume of Hexane Extract in mL } \\
\cline { 2 - 5 } & $\mathbf{0 . 1} \mathbf{m L}$ & $\mathbf{0 . 5} \mathbf{m L}$ & $\mathbf{1 . 0 m L}$ & Control \\
\hline Neisseria gonorrhea & - & $* 15 \pm 0.2$ & $* 20 \pm 0.2$ & - \\
\hline Escherichia coli & - & - & - & - \\
\hline Pseudomonas aeruginosa & - & - & - & - \\
\hline Staphylococcus aureus & $* 6 \pm 0.4$ & $* 15 \pm 0.4$ & $* 18 \pm 0.4$ & - \\
\hline Candida albicans & $* 5 \pm 0.1$ & $* 15 \pm 0.3$ & $* 21 \pm 0.4$ & - \\
\hline
\end{tabular}

Key:

*Zone of Inhibition in millilitre ( $\mathrm{mm}$ ) in triplicate expressed as means and standard error of means.

Table 3. Antimicrobial activity of the ethanolic extracts of Jatropha curcas root on different test organisms

\begin{tabular}{|l|c|c|c|c|}
\hline \multirow{2}{*}{\multicolumn{1}{c|}{ Organism }} & \multicolumn{4}{|c|}{ Volume of Ethanol Extract in mL } \\
\cline { 2 - 5 } & $\mathbf{0 . 1} \mathbf{m L}$ & $\mathbf{0 . 5 m L}$ & $\mathbf{1 . 0 m L}$ & control \\
\hline Neisseria gonorrhea & - & $* 4 \pm 0.2$ & $* 12 \pm 0.2$ & - \\
\hline Escherichia coli & $* 5 \pm 0.4$ & $* 13 \pm 0.4$ & $* 17 \pm 0.4$ & - \\
\hline Pseudomonas aeruginosa & - & $* 12 \pm 0.2$ & $* 16 \pm 0.2$ & - \\
\hline Staphylococcus aureus & - & $* 5 \pm 0.4$ & $* 11 \pm 0.4$ & - \\
\hline Candida albicans & - & - & - & - \\
\hline
\end{tabular}

Key: *Zone of Inhibition measured in millilitre (mm)

Each value is the overall mean and standard deviation of three determinations.

-, No zone of inhibition

Table 4. Antimicrobial activity of the aqueous extracts of Jatropha curcas root on different test organisms

\begin{tabular}{|l|c|c|c|c|}
\hline \multirow{2}{*}{\multicolumn{1}{c|}{ Organism }} & \multicolumn{4}{|c|}{ Volume of Aqueous Extract in mL } \\
\cline { 2 - 5 } & $\mathbf{0 . 1 m L}$ & $\mathbf{0 . 5 m L}$ & $\mathbf{1 . 0 m L}$ & control \\
\hline Neisseria gonorrhea & $* 4 \pm 0.3$ & $* 8 \pm 0.7$ & $* 15 \pm 0.2$ & - \\
\hline Escherichia coli & $* 5 \pm 0.4$ & $* 10 \pm 0.6$ & $* 12 \pm 0.4$ & - \\
\hline Pseudomonas aeruginosa & - & - & - & - \\
\hline Staphylococcus aureus & $* 7 \pm 0.3$ & $* 12 \pm 0.1$ & $* 17 \pm 0.5$ & - \\
\hline Candida albicans & - & - & - & - \\
\hline
\end{tabular}

Key: *Zone of Inhibition in millilitre $(\mathrm{mm})$ in triplicate expressed as means and standard error of means -, = No zone of inhibition

Table 5. Antimicrobial activity of the Jatropha curcas latex on different test organisms

\begin{tabular}{|l|c|c|c|c|}
\hline \multirow{2}{*}{\multicolumn{1}{|c|}{ Organism }} & \multicolumn{4}{c|}{ Volume of Latex } \\
\cline { 2 - 5 } & $\mathbf{0 . 1} \mathbf{m L}$ & $\mathbf{0 . 5 m L}$ & $\mathbf{1 . 0 m L}$ & Control \\
\hline Neisseria gonorrhea & - & - & $* 3 \pm 0.6$ & - \\
\hline Escherichia coli & - & $* 7 \pm 0.4$ & $* 11 \pm 0.5$ & - \\
\hline Pseudomonas aeruginosa & - & $* 9 \pm 0.3$ & $* 15 \pm 0.2$ & - \\
\hline Staphylococcus aureus & $* 3 \pm 0.6$ & $* 10 \pm 0.3$ & $* 22 \pm 0.4$ & - \\
\hline Candida albicans & - & - & $* 4 \pm 0.8$ & - \\
\hline
\end{tabular}

Key: *Zone of Inhibition measured in millilitre ( $\mathrm{mm})$;

Each value is over all mean and standard deviation of three determinations

-, = No zone of inhibition 
Table 6. Antifungal activity of the root extracts of Jatropha curcas against Aspergillus flavus.

\begin{tabular}{|c|c|c|c|c|}
\hline \multirow{2}{*}{ Extract } & \multicolumn{3}{|c|}{ Volume of Extract (mL) } & \multirow{2}{*}{ Control } \\
\cline { 2 - 4 } & $\mathbf{0 . 1} \mathbf{m L}$ & $\mathbf{0 . 5 m L}$ & $\mathbf{1 . 0 m L}$ & \\
\hline HEJCR & $* 19 \pm 0.5$ & $* 17 \pm 0.2$ & $* 13 \pm 0.6$ & 19 \\
\hline EEJCR & $* 21 \pm 0.7$ & $* 17 \pm 0.3$ & $* 16 \pm 0.1$ & 20 \\
\hline AEJCR & $* 15 \pm 0.3$ & $* 15 \pm 0.7$ & $* 14 \pm 0.2$ & 16 \\
\hline Latex & $* 24 \pm 0.4$ & $* 21 \pm 0.8$ & $* 18 \pm 0.6$ & 20 \\
\hline
\end{tabular}

KEY: *Zone of Inhibition measured in millilitre (mm)

Each value is over all mean and standard deviation of three determinations; -, = No zone of inhibition; HEJCR = Hexane extract; EEJCR = Ethanolic extract ; AEJCR = Aqueous extract

Table 7. Minimum inhibitory concentration (MIC) of root extracts and latex of Jatropha curcas plant

\begin{tabular}{|c|c|c|c|c|c|c|c|c|c|c|c|c|c|c|c|c|c|c|c|c|c|c|c|c|c|}
\hline \multirow{2}{*}{ Organism } & \multicolumn{6}{|c|}{ Hexane Extract (mL) } & \multicolumn{6}{|c|}{ Ethanol Extract (mL) } & \multicolumn{6}{|c|}{ Aqueous Extract (mL) } & \multicolumn{6}{|c|}{ Latex (mL) } & \multirow{2}{*}{$\begin{array}{l}\text { Control } \\
1.0(\mathrm{~mL}) \\
\end{array}$} \\
\hline & 0.05 & 0.1 & 0.3 & 0.5 & 1 & 2 & 0.05 & 0.1 & 0.3 & 0.5 & 1 & 2 & 0.05 & 0.1 & 0.3 & 0.5 & 1 & 2 & 0.05 & 0.1 & 0.3 & 0.5 & 1 & 2 & \\
\hline $\begin{array}{l}\text { Neisseria } \\
\text { gonorrhoea }\end{array}$ & + & + & - & - & - & - & + & + & - & - & - & - & - & - & - & - & - & - & + & + & + & + & - & - & + \\
\hline $\begin{array}{l}\text { Escherichia } \\
\text { coli }\end{array}$ & + & + & + & + & + & + & - & - & - & - & - & - & - & - & - & - & - & - & + & - & - & - & - & - & + \\
\hline $\begin{array}{l}\text { Pseudomonas } \\
\text { aeruginosa }\end{array}$ & + & + & + & + & + & + & - & - & - & - & - & - & + & + & + & + & + & + & + & - & - & - & - & - & + \\
\hline $\begin{array}{l}\text { Staphylococcus } \\
\text { aureus }\end{array}$ & - & - & - & - & - & - & + & - & - & - & - & - & - & - & - & - & - & - & - & - & - & - & - & - & + \\
\hline $\begin{array}{l}\text { Candida } \\
\text { albicans }\end{array}$ & - & - & - & - & - & - & + & + & + & + & + & + & + & + & + & + & + & + & + & + & + & + & + & + & + \\
\hline
\end{tabular}

KEY:

,$+=$ Growth indicated no inhibition $\quad-,=$ No growth indicated inhibition

Table 8. Determination of minimum inhibitory concentration of extracts and latex against Aspergillus flavus

\begin{tabular}{|c|c|c|c|c|c|c|c|}
\hline \multirow{2}{*}{ Extract } & \multicolumn{6}{|c|}{ Volume of Extract (mL) } & \multirow{2}{*}{ Control } \\
\hline & 0.05 & 0.10 & $\mathbf{0 . 3 0}$ & 0.5 & 1.0 & 2.0 & \\
\hline HEJCR & + & + & + & + & + & RMG & + \\
\hline EEJCR & + & + & + & $\mathrm{RMG}$ & RMG & RMG & + \\
\hline AEJCR & + & + & + & + & + & RMG & + \\
\hline Latex & + & + & + & + & RMG & RMG & + \\
\hline
\end{tabular}

Key:,$+=$ Growth indicated no inhibition

$\mathrm{RMG}=$ Reduction of mycelial growth

HEJCR $=$ Hexane extract

EEJCR $=$ Ethanolic extract

$\mathrm{AEJCR}=$ Aqueous extract 